\title{
Health of the People: The Highest Law?
}

Lawrence O. Gostin

Georgetown University Law Center, gostin@law.georgetown.edu

This paper can be downloaded free of charge from:

https://scholarship.law.georgetown.edu/facpub/1806

32 J.L. Med. \& Ethics 509-515 (2004)

This open-access article is brought to you by the Georgetown Law Library. Posted with permission of the author. Follow this and additional works at: https://scholarship.law.georgetown.edu/facpub

Part of the Health Law and Policy Commons 


\title{
Health of the People: The Highest Law?
}

\author{
Lawrence O. Gostin
}

From my perspective, as a White House official watching the budgetary process, and subsequently as head first of a health care financing agency and then of a public health agency, I was continually amazed to watch as billions of dollars were allocated to financing medical care with little discussion, whereas endless arguments ensued over a few millions for community prevention programs. The sums that were the basis for prolonged, and often futile, budget fights in public health were treated as rounding errors in the Medicare budget.

William Roper (1994)

$\mathrm{L}$ aw and ethics in population health are undergoing a renaissance. ${ }^{1}$ Once fashionable during the Industrial ${ }^{2}$ and Progressive $^{3}$ eras, the ideals of population health began to wither with the rise of liberalism in the late twentieth century. ${ }^{4}$ In their place came a sharpened focus on personal and economic freedom. Political attention shifted from population health to individual health and from public health to private medicine.

Signs of revitalization of the field of public health law and ethics can be seen in diverse national and global contexts. ${ }^{5}$ International agencies, national governments, and philanthropic organizations are creating centers of excellence in public health law and ethics; ${ }^{6}$ initiating broad reforms of antiquated public health laws; ${ }^{7}$ and calling for effective public health governance systems at the global level. ${ }^{8}$ The resurgence of interest in population-based law and ethics deserves vigorous attention in modern political and social circles. However, it is not easy to sell population health in the marketplace of ideas. ${ }^{9}$ Why is public health action politically and publicly underappreciated?: (1) The rescue imperative - society is willing to spend inordinately to save a life of a person with a name, face, and history, but less so to save "statistical lives;"10 (2) The technological imperative - public health services are less appealing and salient than the high technology solutions of microbiology and genetics; (3) The invisibility of public health when public health is working well (e.g., safe food, water, and products), its importance is taken for granted; and (4) The culture of individualism - society often values personal goods (individual responsibility, choice, and satisfaction) over public goods (population health and safety).

The field of public health law and ethics needs a theory and definition (what is public health law and ethics and what are its doctri- nal boundaries?); a well-articulated vision (why should health be a salient public value?); and an assessment of law as a tool to promote the public's health (how can law be effective in reducing morbidity and premature mortality?). This paper begins an exploration, which can be fully developed only through the thinking and practice of dedicated public health scholars and advocates.

\section{Public Health and the Law: \\ A Theory and a Definition}

Liberty does not import an absolute right in each person to be, at all times and in all circumstances, wholly freed from restraint. There are manifold restraints to which every person is necessarily subject for the common good. On any other basis organized society could not exist with safety to its members....A fundamental principle of the social compact is that the whole people covenants with each citizen, and each citizen with the whole people, that all shall be governed by certain laws for the common good, and that government is instituted for the common good, for the protection, safety, prosperity and happiness of the people, and not for the profit, honor or private interests of any one man, family or class of men.

Justice John Harlan (1905)

The literature on the intersection of law and health is pervasive and the subject is widely taught, practiced, and analyzed. The fields that characterize these branches of study are variously called health care law, law and medicine, and forensic medicine. Do these names imply different disciplines, each with a coherent theory, structure, and method that set it apart? Notably absent from the extant literature is a theory of public health law and an exploration of its boundaries. I define public health law as follows:

The study of the legal powers and duties of the state to promote the conditions for people to be healthy (e.g., to identify, prevent, and ameliorate significant risks to health in the population) and the limita-

Lawrence O. Gostin, J.D., is the John Carroll Research Professor of Law, Georgetown University; Professor of Public Health, the Johns Hopkins University; and Director, Center for Law छ the Public's Health. As a Member of the Institute of Medicine (IOM), Prof. Gostin sits on the IOM Board on Health Promotion and Disease Prevention, was a member of the IOM Committee on the Future of the Public's Health, and currently chairs the IOM Committee on Genomics in Population Health in the 21st Century. 
tions on the power of the state to constrain the autonomy, privacy, liberty, proprietary, or other legally protected interests of individuals for the protection or promotion of community health.

Through this definition, I suggest five essential characteristics of public health law: (1) Government - Public health is a special responsibility of government, in collaboration with partners in the community, business, the media and academia. ${ }^{\text {II }}$ (2) Populations - Public health focuses on the health of populations rather than individual patients. (3) Relationships - Public health addresses the relationship between the state and the population (or between the state and individuals who place themselves or the community at risk). (4) Services - Public health deals with the provision of population-based services grounded on the scientific methodologies of public health (e.g., biostatistics and epidemiology). (5) Power - Public health authorities possess the power to regulate individuals and businesses for the protection of the community, rather than relying on the ethic of voluntarism.

A systematic understanding of public health law requires an examination of the terms "public health" and the "common good." The word "public" in public health has two overlapping meanings - one that explains the entity that takes primary responsibility for the public's health, and another that explains who has a legitimate expectation to receive the benefits. The government has primary responsibility for the public's health. The government is a "public" entity that acts on behalf of the people and gains its legitimacy through a political process. A characteristic form of "public" or state action occurs when a democratically elected government exercises powers or duties to protect or promote the population's health.

The population as a whole has a legitimate expectation to benefit from public health services. The population elects the government and holds the state accountable for a meaningful level of health protection. Public health should possess broad appeal to the electorate because it is truly a universal aspiration. What best serves the population, of course, may not always be in the interests of all its members. And it is for this reason that public health is in fact highly political. What constitutes "enough" health? What kinds of services? How will services be paid for and distributed? These remain political questions.

If individual interests are to give way to communal interests in healthy populations, it is important to understand the value of "the common" and "the good."

The field of public health would profit from a vibrant conception of "the common" that sees public interests as more than the aggregation of individual interests. A nonaggregative understanding of public goods recognizes that everyone has a stake in living in a society that regulates risks that all share. Laws designed to promote the common good may sometimes constrain individual actions (smoking in public places, riding a motorcycle without a helmet, etc.). As members of society, we have common goals that go beyond our narrow interests. Individuals have a stake in healthy and secure communities where they can live in peace and well-being. An unhealthy or insecure community may produce harms common to all such as increased crime and violence, impaired social relationships, and a less productive workforce. Consequently, people may have to forgo a little bit of self-interest in exchange for the protection and satisfaction gained from sustaining healthier and safer communities.

We also need to better understand the concept of "the good." In medicine, the meaning of "the good" is defined purely in terms of the individual's wants and needs. It is the patient, not the physician or family, who decides the appropriate course of action. In public health, the meaning of "the good" is far less clear. Who gets to decide in a given case which value is more important - freedom or health? One strategy for public health decision-making would be to allow each person to decide, but this would thwart many public health initiatives. For example, if individuals could decide whether to acquiesce to a vaccination or to permit reporting of personal information to the health department, it would result in a "tragedy of the commons." 2

One way forward is to promote greater community involvement in public health decision-making so that policy formation becomes a genuinely civic endeavor. ${ }^{13}$ Citizens would strive to safeguard their communities through civic participation, open fora, and capacity building to solve local problems. Public involvement should result in stronger support for health policies and encourage citizens to take a more active role in protecting themselves and the health of their neighbors.

Public health law, therefore, places special responsibility on government to serve the health needs of populations. It is highly political, so that public health advocates should not shy away from energetic, ongoing involvement in the political process. It is also highly participatory, so that advocates should closely collaborate with affected communities.

\section{The Future of the Public's Health: From Personal Rights to Societal Obligations}

Measures to improve public health, relating as they do to such obvious and mundane matters as housing, smoking, and food, may lack the glamour of high-technology medicine, but what they lack in excitement they gain in their potential impact on health, precisely because they deal with the major causes of common disease and disabilities.

Geoffrey Rose (1992)

One reason for the decline in emphasis on public health was that libertarianism flourished during the late twentieth century. This was a time when scholars had great influence in shaping ideas about the salience of the individual. Both ends of the political spectrum celebrated the values of free will and personal choice. The political left espoused the virtues of civil liberties, stressing autonomy, privacy, and liberty. At the same time, the political right espoused the virtues of economic liberty, stressing freedom of contract, property privileges, and competitive markets. Personal interests in self-determination attained the status of "rights." Citizens were transformed from passive recipients of government largess into rights holders. In this intellectual environment, the individual's own interests often prevailed over the interests of family, community, or country.

Certainly, the power and importance of individual freedom is beyond dispute. However, insufficient attention has been given to the equally strong values of partnership, citizenship, and community. We need to recapture a classic republican tradition that emphasizes communal obligations as well as self-importance. As members of a society we all have a common bond. Our responsibility is not simply to defend our own right to be free from economic and personal restraint. We also have an obligation to protect and defend the community against threats to health, safety, and security. Each member of society owes a duty - one to another - to promote the common good. And each member benefits from participating in a well-regulated society that reduces risks that all members share. People may have to forgo a small sphere of self-interest in exchange for the protection and satisfaction gained from living in a community where public health is recognized as an important value.

\section{Public Health's Vision: Why Population Health Should Be a Salient Public Value}

The success or failure of any government in the final analysis must be measured by the well-being of its citizens. Nothing 
can be more important to a state than its public health; the state's paramount concern should be the health of its people. Franklin Delano Roosevelt (1932)

The public health community takes it as an act of faith that health must be society's overarching value. Yet politicians do not always see it that way, expressing preferences, say, for highways, energy, and the military. The lack of political commitment to population health can be seen in the relatively low public health expenditures in many national budgets. ${ }^{14}$ Public health professionals often distrust and shun politicians rather than engage them in dialogue about the importance of population health. What is needed is a clear vision of, and rationale for, healthy populations as a political priority.

Why should health be a salient public value, as opposed to other communal goods such as transportation, energy, or national security? Two interrelated theories support the role of health as a primary value: (1) a theory of human functioning - health is a foundation for personal well-being and the exercise of social and political rights; and (2) a theory of democracy - governments are formed primarily to achieve health, safety, and welfare for the population.

\section{Health is Foundational: \\ A Theory of Human Functioning}

Health is foundationally important because of its intrinsic value and its singular contribution to human functioning. Health takes on a special meaning and importance to individuals and the community as a whole. ${ }^{15}$ Every person understands, at least intuitively, why health is vital to well-being. Health is necessary for much of the joy, creativity, and productivity that a person derives from life. If individuals have physical and mental health they are better able to recreate, socialize, work, and engage in the activities of family and social life that bring meaning and happiness. Certainly, persons with ill-health or disability can lead deeply fulfilling lives, but personal health does facilitate many of life's joys and accomplishments. Every person strives for the best physical and mental health achievable, even in the face of existing disease, injury, or disability. People's health is so instinctively essential that human rights norms embrace the right to health. ${ }^{16}$

Perhaps not as obvious, however, health is also essential for the functioning of populations. Without minimum levels of health, people cannot fully engage in social interactions, participate in the political process, exercise rights of citizenship, generate wealth, create art, and provide for the common security. A safe and healthy population builds strong roots for a country - its governmental structures, social organizations, cultural endowment, economic prosperity, and national defense. Population health, then, becomes a transcendent value because a certain level of human functioning is a prerequisite for engaging in activities that are critical to the public welfare - social, political, and economic.

Health has an intrinsic and instrumental value for individuals, communities, and entire nations. People aspire to achieve health because of its importance to a satisfying life; communities promote the health of their neighbors for the mutual benefits of social interactions; and nations build health care and public health infrastructures to cultivate a decent and prosperous civilization.

\section{Government's Obligation to Promote Health: A Theory of Democracy}

Why is it that government has an enduring obligation to protect and promote the public's health? Theories of democracy help to explain the role of government in matters of population health. People form governments for their common defense, security, and welfare - goods that can only be achieved through collective action. The first thing that public officials owe to their constituents is protection against natural and manmade hazards. Public health is a classic case of a general communal provision because public funds are expended to ben- efit all or most of the population without any specific distribution to individuals. ${ }^{17}$

A political community stresses a shared bond among members: organized society safeguards the common goods of health, welfare, and security, while members subordinate themselves to the welfare of the community as a whole. ${ }^{18}$ Public health can be achieved only through collective action, not through individual endeavor. Acting alone, individuals cannot assure even minimum levels of health. Any person of means can procure many of the necessities of life - e.g., food, housing, clothing, and even medical care. Yet no single individual, or group of individuals, can assure his or her health. Meaningful protection and assurance of the population's health require communal effort. The community as a whole has a stake in environmental protection, hygiene and sanitation, clean air and surface water, uncontaminated food and drinking water, safe roads and products, and control of infectious disease. These collective goods, and many more, are essential conditions for health. Yet these benefits can be secured only through organized action on behalf of the people.

Therefore, in a democracy, political officials are at least putatively committed to securing health for the population, and members of the community are committed to bear the necessary burdens. In a democracy, tradeoffs between individual rights and common goods can be made by the populace, ensuring a greater level of fairness and promoting adherence to governmental regulation. While countries without democracy are capable of securing some level of public health, the level of commitment to public health goals is dictated by the government (which may place a greater value on remaining in power) instead of being determined by the people. The collective efforts of the body politic to protect and promote the population's health represent a central theoretical tenet of what we call public health ethics.

\section{Law as a Tool to Protect the Public's Health: Models of Public Health Intervention}

At the heart of the well regulated society was a plethora of bylaws, ordinances, statutes, and common law restrictions regulating nearly every aspect of economy and society.... [Regulations in a good society] granted to public officials the power to guarantee public health (securing the population's well-being, longevity, and productivity). Public health regulation ... was the central component of a reigning theory and practice of governance committed to the pursuit of the people's welfare and happiness in a well-ordered society and polity.

William J. Novak (1996)

If government has an obligation to promote the conditions for people to be healthy, what tools are at its disposal? There are at least seven models for legal intervention designed to prevent injury and disease, encourage healthful behaviors, and generally promote the public's health. The interventions vary in terms of their coerciveness. Therefore, different interventions may be more or less justifiable as solutions to various problems. Although legal interventions can be effective, they often raise critical social, ethical, or constitutional concerns that warrant careful study. Public health law is intellectually enticing precisely because it is so difficult, involving complex tradeoffs between individual and collective interests.

\section{Model 1: The Power to Tax and Spend}

The power to tax and spend is ubiquitous in national constitutions, providing government with an important regulatory technique. The power to spend supports the public health infrastructure consisting of: a well-trained workforce, electronic information and communications systems, rapid disease surveillance, laboratory capacity, and response capability. ${ }^{19}$ The state can also set health-related conditions for the receipt of public funds. For example, government can grant funds for highway construction or other public works projects on the condi- 
tion that the recipients meet designated safety requirements. ${ }^{20}$

The power to tax provides inducements to engage in beneficial behavior and disincentives to engage in risk activities. Tax relief can be offered for health producing activities such as medical services, childcare, and charitable contributions. At the same time, tax burdens can be placed on the sale of hazardous products such as cigarettes, alcoholic beverages, and firearms. Studies demonstrate that taxation policy has a significant influence on healthful or risk behaviors, particularly among young people. ${ }^{21}$

Despite their undoubted effectiveness, the spending and taxing powers are not entirely benign. Taxing and spending can be seen as coercive because the government wields significant economic power. They can also be viewed as inequitable if rich people benefit, while the poor are disadvantaged. Some taxing policies serve the rich, the politically connected, or those with special interests (e.g., tax preferences for energy companies or tobacco farmers). Other taxes penalize the poor because they are highly regressive. For example, almost all public health advocates support cigarette taxes, but the people who shoulder the principal financial burden are disproportionately indigent and are often in minority groups.

\section{Model 2: The Power to Alter the Informational Environment}

The public is bombarded with information that influences life's choices, and this undoubtedly affects health and behavior. ${ }^{22}$ The government has several tools at its disposal to alter the informational environment, encouraging people to make more healthful choices about diet, exercise, cigarette smoking, and other behaviors.

First, government, as a health educator, uses communication campaigns as a major public health strategy. Health education campaigns, like other forms of advertising, are persuasive communications; instead of promoting a product or a political philosophy, public health promotes safer, more healthful behaviors. Prominent campaigns include safe driving, safe sex, and nutritious diets.

Second, government can require businesses to label their products to include: instructions for safe use, disclosure of contents or ingredients, and health warnings. For example, government requires businesses to explain the dosage and adverse effects of pharmaceuticals, reveal the nutritional and fat content of foods, and warn consumers of the health risks of smoking and drinking alcoholic beverages.

Finally, government can limit harmful or misleading information in private advertising. The state can ban or regulate advertising of potentially harmful products such as cigarettes, firearms, and even high-fat foods. Advertisements can be deceptive or misleading by, for example, associating dangerous activities such as smoking with sexual, adventurous, or active images. Advertisements can also exacerbate health disparities by, for example, targeting product messages to vulnerable populations such as children, women, or minorities.

To many public health advocates, there is nothing inherently wrong with, or controversial in, ensuring that consumers receive full and truthful information. Yet, not everyone believes that public funds should be expended, or the veneer of government legitimacy used, to prescribe particular social orthodoxies - sex, abortion, smoking, highfat diet, or sedentary lifestyle. Labeling requirements seem unobjectionable, but businesses strongly protest compelled disclosure of certain kinds of information. For example, should businesses be required to label foods as genetically modified? GM foods have not been shown to be dangerous to humans, but the public demands a "right to know." Advertising regulations restrict commercial speech, thus implicating businesses' right to "freedom of expression." The U.S. Supreme Court, for example, has strongly supported the "right" to convey "truthful" commercial information. ${ }^{23}$ Courts in most liberal democracies, however, do not afford protection to corporate speech. ${ }^{24}$ There is, after all, a distinction between political and social speech (which deserve rigorous legal protection) and commercial speech. The former is neces- sary for a vibrant democracy, while the latter is purchased and seeks primarily to sell products for a profit.

\section{Model 3: The Power to Alter the Built Environment}

The design of the built or physical environment can hold great potential for addressing the major health threats facing the global community. Public health has a long history in designing the built environment to reduce injury (e.g., workplace safety, traffic calming, and fire codes), infectious diseases (e.g., sanitation, zoning, and housing codes), and environmentally associated harms (e.g., lead paint and toxic emissions).

Many developed countries are now facing an epidemiological transition from infectious to chronic diseases such as cardiovascular disease, cancer, diabetes, asthma, and depression. The challenge is to shift to communities designed to facilitate physical and mental wellbeing. Although research is limited, ${ }^{25}$ we know that environments can be designed to promote livable cities and facilitate health-affirming behavior by, for example: encouraging more active lifestyles (walking, biking, and playing); improving nutrition (fruits, vegetables, and avoidance of high-fat, high-caloric foods); decreasing use of harmful products (cigarettes and alcoholic beverages); reducing violence (domestic abuse, street crime, and firearm use); and increasing social interactions (helping neighbors and building social capital). ${ }^{26}$

Critics offer a stinging assessment of public health efforts to alter the built environment: "The anti-sprawl campaign is about telling [people] how they should live and work, about sacrificing individuals' values to the values of their politically powerful betters. It is coercive, moralistic, nostalgic, [and lacks honesty]."27 This critique fails to take account of history, norms, and evidence. ${ }^{28}$ Historically, government has been actively involved in land use planning. ${ }^{29}$ It is not a matter of whether the state should plan cities and towns, but how. Government makes land use planning decisions to achieve many public purposes, and a nation's health and safety are normatively quite important. The evidence demonstrates that organized societies have a remarkable capacity to plan, shape the future, and help populations increase health and well-being. ${ }^{30}$ History, theory and empirical evidence do not make it inevitable that the state will, or always should, prefer health-enhancing policies. However, government does have an obligation to carefully consider the population's health in its land use policies.

\section{Model 4: The Power to Alter the Socio-Economic Environment}

A strong and consistent finding of epidemiological research is that socio-economic status (SES) is correlated with morbidity, mortality, and functioning. ${ }^{31}$ SES is a complex phenomenon based on income, education, and occupation. The relationship between SES and health often is referred to as a "gradient" because of the graded and continuous nature of the association; health differences are observed well into the middle ranges of SES. These empirical findings have persisted across time ${ }^{32}$ and cultures, ${ }^{33}$ and remain viable today. For example, researchers have demonstrated socio-economic differentials in the health-related quality of life of Australian children, ${ }^{34}$ and similar disparities can be found in vulnerable populations in North America $^{35}$ and Europe. ${ }^{36}$

Some researchers go further, suggesting the overall level of socioeconomic inequality in a society affects health. ${ }^{37}$ That is, societies with fewer inequalities between the rich and poor tend to have superior health status. This phenomenon is apparent in comparisons of health indicators in Organization for Economic Co-operation and Development (OECD) countries, where life expectancy is higher in countries with well-developed social welfare systems that assure greater equity in resource allocation. ${ }^{38}$ The explanatory variables are hypothesized to be the lack of social support and cohesion in unequal 
societies. Some ethicists, relying on these studies, claim, "Social justice is good for our health."39

Despite the strength of evidence, critics express strong objections to policies directed to reducing socio-economic disparities. ${ }^{40}$ First, they dispute the causal relationship between low SES and poor health outcomes. The poor, they suggest, may have worse health not because of income but for some other reason such as genetic differences, risk behaviors, or reduced access to health care or education. Or, they suggest the causal relationship may be in the other direction - poor health causes low income due to an inability to work or high medical costs. Second, critics infer that reduction in disparities entails redistribution of wealth; greater SES equality necessarily requires programs designed to lift people out of poverty and impoverished conditions. Income reallocation and disruption of competitive markets, they claim, would have adverse economic effects including reduced efficiency and productivity; these economic effects, in turn, could be detrimental to health. ${ }^{41}$ Consequently, reduction of SES disparities should be a political, not a public health, decision.

Although SES disparities are political questions, the evidence should guide elected officials. Admittedly, the explanatory variables for the relationship between SES and health are not entirely understood. However, waiting for researchers to definitively find the causal pathways would be difficult and time-consuming given the multiple confounding factors. This would indefinitely delay policies that could powerfully affect people's health and longevity. What we do know is that the gradient probably involves multiple pathways, each of which can be addressed through social policy. ${ }^{42}$ People of low SES experience material disadvantage (e.g., access to food, shelter, and health care); toxic physical environments (e.g., poor conditions at home, work, and community); psychosocial stressors (e.g., financial or occupational insecurity and lack of control); and social contexts that influence risk behaviors (e.g., smoking, physical inactivity, high-fat diet, and excessive alcohol consumption). Society can work to try to alleviate each of these determinants of morbidity and premature mortality.

\section{Model 5: Direct Regulation of Persons, Professionals, and Businesses}

Government has the power to directly regulate individuals, professionals, and businesses. In a well-regulated society, public health authorities set clear, enforceable rules to protect the health and safety of workers, consumers, and the population at large. Regulation of individual behavior (e.g., use of seatbelts and motorcycle helmets) reduces injuries and deaths. Licenses and permits enable government to monitor and control the standards and practices of professionals and institutions (e.g., doctors, hospitals, and nursing homes). Finally, inspection and regulation of businesses helps to assure humane conditions of work, reduction in toxic emissions, and safer consumer products.

Despite its undoubted value, public health regulation of commercial activity is highly contested terrain. Influential economic theories (e.g., laissez-faire and, more recently, a market economy) favor open competition and the undeterred entrepreneur. ${ }^{43}$ Libertarians view commercial regulation as detrimental to economic growth and social progress. Commercial regulation, they argue, should redress market failures (e.g., monopolistic and other anticompetitive practices) rather than restrain free trade. Yet, public health advocates are opposed to unfettered private enterprise and suspicious of free-market solutions to complex social problems. ${ }^{44}$ Unbridled commercialism can produce unsafe work environments; noxious by-products such as waste or pollution; and public nuisances such as unsafe buildings or accumulations of garbage. Regulation is needed to curb the excesses of unrestrained capitalism to ensure reasonably safe and healthful business practices.

\section{Model 6: Indirect Regulation Through the Tort System}

Attorneys general, public health authorities, and private citizens possess a powerful means of indirect regulation through the tort system. Civil litigation can redress many different kinds of public health harms: environmental damage (e.g., air pollution or groundwater contamination); exposure to toxic substances (e.g. pesticides, radiation, or chemicals); hazardous products (e.g., tobacco or firearms); and defective consumer products (e.g., children's toys, recreational equipment, or household goods). For example, tobacco companies, in 1998, negotiated a Master Settlement Agreement with American states that required compensation in perpetuity, with payments totaling $\$ 206$ billion through the year 2025.45

The goals of tort law, although imperfectly achieved, are frequently consistent with public health objectives. The tort system aims to hold individuals and businesses accountable for their dangerous activities, compensate persons who are harmed, deter unreasonably hazardous conduct, and encourage innovation in product design. Civil litigation, therefore, can provide potent incentives for people and manufacturers to engage in safer, more socially conscious behavior.

While tort law can be an effective method of advancing the public's health, like any form of regulation, it is not an unmitigated good. First, the tort system imposes economic costs and personal burdens on individuals and businesses (liability and "transaction" expenses such as court costs and attorneys' fees). Tort costs are absorbed by the enterprise, which often passes the costs onto employees and consumers. Second, tort costs may be so high that businesses do not enter the market, leave the market, or curtail research and development. Society may not be any poorer if tort costs drive out socially unproductive enterprises (e.g., tobacco or firearms), but not socially advantageous enterprises (e.g., vaccines and pharmaceuticals). Third, the tort system may be unfair, distributing windfalls to isolated plaintiffs and their attorneys, while failing to compensate the majority of injured people in the population. Studies of the medical malpractice system, for example, demonstrate that large awards often are given to undeserving plaintiffs while most patients who suffer from medical error are never compensated. ${ }^{46}$

Model 7: Deregulation: Law as a Barrier to Health Sometimes laws are harmful to the public's health and stand as an obstacle to effective action. In such cases, the best remedy is deregulation. Politicians may urge superficially popular policies that have unintended health consequences. Consider laws that penalize exchanges or pharmacy sales of syringes and needles. Restricting access to sterile drug injection equipment can fuel the transmission of HIV infection. Similarly, the closure of bathhouses can drive the epidemic underground, making it more difficult to reach gay men with condoms and safe sex literature. Finally, laws that criminalize sex unless the person discloses his or her HIV-status make common sexual behavior unlawful. The criminal law provides a disincentive for seeking testing and medical treatment, ultimately harming the public's health. ${ }^{47}$

Deregulation can be controversial since it often involves a direct conflict between public health and other social values such as crime prevention or morality. Drug laws, the closure of bathhouses, and HIV-specific criminal penalties represent society's disapproval of dis- 
favored behaviors. Deregulation becomes a symbol of weakness that is often politically unpopular. Despite the political dimensions, public officials should give greater attention to the health effects of public policies, as the next section makes evident.

The government, then, has many legal "levers" designed to prevent injury and disease and promote the public's health. Legal interventions can be highly effective and need to be part of the public health officer's arsenal. However, legal interventions can be controversial, raising important ethical, social, constitutional, and political issues. These conflicts are complex, important, and fascinating for students of public health law.

\section{Conclusion}

I desire, in closing this series of introductory papers, to leave one great fact clearly stated. There is no wealth but life. Life, including all its powers of love, of joy, and of admiration. That country is richest which nourishes the greatest number of noble and happy human beings; that man is richest, who, having perfected the functions of his own life to the utmost, has also the widest helpful influence, both personal, and by possessions, over the lives of others.

John Ruskin (1862)

This paper has proposed an action agenda to help attain healthier and safer populations:

- Create a strong public health infrastructure with sustainable funding and secure foundations: ensure a well-trained workforce, modern data systems, rapid disease surveillance, laboratory capacity, and response capability.

- Help communities use law as a tool for health promotion and disease prevention: tax and spend to create incentives for healthy activities, alter the informational and built environments to reduce risk behaviours, lower economic disparities to improve morbidity and mortality, regulate for the public's welfare, pursue tort litigation to innovate for safety, and deregulate to reduce harm.

- Create a new public health ethic in society that truly values the health and welfare of the people: advocate for a renewed commitment to the ideals of community and partnership, and stress citizens' duties to help and protect their fellow human beings.

In the late twentieth century scholars and politicians posed a key question: "What desires and needs do you have as an autonomous, rights-bearing person to privacy, liberty, and free enterprise?" Now it is important to ask another kind of question, equally important to human well-being: "What kind of a community do you want and deserve to live in, and what personal interests are you willing to forgo to achieve a good and healthful society?" Using law as a tool, we can create a community where health is a salient public interest.

\section{Acknowledgments}

This article was presented as the Guest Keynote Address at the conference, "Health of the People: The Highest Law?" January 2004, Queen Elizabeth II Conference Center, London, England, and was sponsored by the Nuffield Trust, the UK Public Health Association, and the Faculty of Public Health of the Royal Colleges of Physicians. I am grateful to John Wyn Owen, Secretary of the Trust, for his leadership in underscoring the value of law in population health. $A$ briefer version of this essay appears in Lawrence $O$. Gostin, "Law and Ethics in Population Health," Australia $\mho^{\circ}$ Nere Zealand Journal of Public Health 28 (2004): 7-12. For an expanded version of the ideas in this essay, see my two books both published by the University of California Press and the Milbank Memorial Fund: Lawrence O. Gostin, Public Health Law: Power, Duty, Restraint (2000) and Public Health Law and Ethics: A Reader (2002), available at <http://www.ucpress.edu/books/pages/9186.html $>$.

\section{References}

1. L. Gostin, "Public Health Law in a New Century: Parts I-III," JAMA 283 (2000): 2837-41, 2979-84, 3118-22; C. Reynolds, "Public Health Law in the New Century," Journal of Law \&' Medicine 10 (2003): 435-41.

2. E. Chadwick, Report on the Sanitary Condition of the Labouring Population of Great Britain (Edinburgh: University Press, 1965); L. Shattuck, Re- port of the Massachusetts Sanitary Commission (Cambridge: Harvard University Press, 1850)

3. J. Duffy, The Sanitarians: A History of American Public Health (Urbana and Chicago: University of Illinois Press, 1990)

4. C. Hamlin, "The History and Development of Public Health in Developed Countries," in R. Detels, J. McEwen, R. Beaglehole, and H. Tanaka, eds., $O x$ ford Textbook of Public Health, 4th ed. (Oxford University Press, 2002): at 21-37.

5. W.W. Holland and S. Stewart, Public Health: The Vision and the Challenge (London: Nuffield Trust, 1997).

6. Center for Law and the Public's Health at Georgetown and Johns Hopkins Universities, at www.publichealthlaw.net; Center for Public Health Law at LaTrobe University, at <http://www.latrobe.edu.au/publichealth/ centre_phl/s.

7. The World Health Organization, International Health Regulations (1983), available at $<\mathrm{http}: / /$ www.who.int/csr/ihr/current/en/>; S. Monaghan, D. Huws, and M. Navarro, The Case for a New UK Health of the People Act (London: The Nuffield Trust, 2003); C. Reynolds, Public Health Law in Australia (Sydney: Federation Press, 1995); I. Bidmeade and C. Reynolds, Public Health Law in Australia: Its Current State and Future Directions (Canberra: Commonwealth of Australia, 1997)

8. J.W. Owen, "Globalization and Public Health," Manchester Medical Society, Chadwick Lecture (April 25, 2002), available at $<\mathrm{http}: / / \mathrm{www}$.nuffieldtrust.org.uk/policy_themes/docs/annualrepspeech2003.doc>; R. Beaglehole, ed., Global Public Health: A Nero Era (Oxford University Press, 2003); D.P. Fidler, International Law and Infectious Diseases (Oxford: Clarendon Press, 1999).

9. G. Rose, "Sick Individuals and Sick Populations," International Journal of Epidemiology 14 (1995): 32-38; S. Burris, "The Invisibility of Public Health. Population-level Measures in a Politics of Market Individualism," American Journal of Public Health 87 (1997): 1607-10.

10. L. Heinzerling, "Regulatory Costs of Mythic Proportions," Yale Law Journal 107 (1998): 1981-2070.

11. Institute of Medicine, The Future of the Public's Health in the Twenty First Century (Washington, DC: National Academy Press, 2003). See L.O Gostin, J.I. Boufford, R.M. Martinez, "The Future of the Public's Health: Vision, Values, and Strategies," Health Affairs 23 (2004): 96-107.

12. G. Hardin, "The Tragedy of the Commons," Science 162 (1968): 1243-48. 13. D. Callahan and B. Jennings, "Ethics and Public Health: Forging a Strong Relationship," American Journal of Public Health 92, no. 2 (2002): 169-76.

14. P. Musgrove, R. Zeramdini, and G. Carrinb, "A Summary Description of Health Financing in WHO Member Countries, Health, Nutrition and Population (HNP) Discussion Paper (2001), available at $<\mathrm{http}$ ://wwwl. worldbank.org/hnp/hsd/rm_wg3_paper11.asp>.

15. N. Daniels, Just Health Care (Cambridge University Press, 1985)

16. The right to the highest attainable standard of health. General Comment $14, \mathrm{E} / \mathrm{C} .12 / 2000 / 4$ (July 4, 2000).

17. M. Walzer, Spheres of Justice: A Defense of Pluralism and Equality (New York: Basic Books, 1983).

18. D.E. Beauchamp, The Health of the Republic: Epidemics, Medicine, and Moralism as Challenges to Democracy (Philadelphia: Temple University Press, 1988).

19. Centers for Disease Control and Prevention, Public Health's Infrastructure: A Status Report (Atlanta: CDC, 2002).

20. South Dakota v. Dole, 483 U.S. 203 (1987).

21. D.M. Fox and D.C. Schaffer, "Tax Administration as Health Policy," Joumal of Health Politics and Policy Law 16 (1991): 251-260.

22. Institute of Medicine, Health and Behavior: The Interplay of Biological, Behavioral, and Societal Influences (Washington, DC: National Academy Press, 2001).

23. Liquormart, Inc. v. Rhode Island, 517 U.S. 484 (1996).

24. Canada Post Corp. v. Epost Innovations Inc., 87 C.R.R.2d. 345 (2001)

25. S. Srinivasan, A. Dearry and L.R. O'Fallon, "Creating Healthy Communities, Healthy Homes, Healthy People: Initiating a Research Agenda on the Built Environment and Public Health," American Journal of Public Health 293 (2003): $1446-50$

26. R. Ewing, T. Schmid, R. Killingsworth, A. Zlot, and S. Raudenbush, "Relationship Between Urban Sprawl and Physical Activity, Obesity, and Morbidity, American Journal of Health Promotion 18, no. I (2003): 47-57.

27. V. Postrel, "The Pleasantville Solution: The War on "Sprawl" Promises 'Livability' but Delivers Repression, Intolerance - and More Traffic," Reason 30 , no. 10 (1999): 4.

28. W.C. Perdue, L.A. Stone, and L.O. Gostin, "The Built Environment and its Relationship to the Public's Health: the Legal Framework," American Journal of Public Health 93 (2003): 1390-94.

29. W.C. Perdue, L.A. Stone, and L.O. Gostin, "Public Health and the Built Environment: Historical, Empirical and Theoretical Foundations for an Expanded Role," Journal of Law, Medicine छ Ethics 31 (2003): 557-566.

30. R.J. Jackson, "The Impact of the Built Environment on Health: An Emerging Field," American Journal of Public Health 93 (2003): 1382-83.

31. E. Rogot, P.D. Sorile, N.J. Johnson, and C. Schmitt, eds. A Mortality Study 
of 1.3 Million Persons by Demographic, Social, and Economic Factors: 19791985 Follow-up (Bethesda, MD: National Institutes of Health, 1992).

32. E.M. Kitagawa, P.M. Hauser, Differential Mortality in the United States: A Study of Socio-economic Epidemiology (Cambridge, MA: Harvard University Press, 1973)

33. M.G. Marmot, G.D. Smith, S. Stansfeld, et al., "Health Inequalities Among British Civil Servants: The Whitehall II Study," Lancet 337, no. 8754 (1991) 1387-93.

34. N.J. Spurrier, M.G. Sawyer, J.J. Clark, and P. Baghurst, "Socio-economic Differentials in the Health-related Quality of Life of Australian Children: Results of a National Study," Australia and New Zealand Journal of Public Health 27 (2003): 27-33.

35. Department of Health and Human Services, Healthy People 2010 (Washington, DC: Government Printing Office, 2000).

36. D. Acheson, Independent Inquiry into Inequalities in Health (London: Stationery Office, 1998).

37. R.G. Wilkinson, Unhealthy Societies: The Afflictions of Inequality (London: Routledge, 1996)

38. C.D. Mathers, C.J.L. Murray, J.A. Salomon, et al., "Healthy Life Expectancy: Comparison of OECD Countries in 2001," Australia and Ner Zealand Journal of Public Health 27 (2003): 5-11.

39. N. Daniels, B. Kennedy, and I. Kawachi, "Justice is Good for Our Health," Boston Reviere 25, no. 1 (2000): 6-15; D.E. Beauchamp, "Public Health as Social Justice," Inquiry 13 (1976): 3-14.

40. A. Deaton, "Policy Implications of the Gradient of Health and Wealth," Health Affairs 21 (2002): 13-30.

41. J.M. Mellor, J.D. Milyo, “Income Inequality and Health Status in the United
States," Joumal of Human Resources 37 (2002): 510-39; A. Garber, "Pursuing the Links Between Socioeconomic Factors and Health," in D.S. Gomby, B.H. Kehrer, eds., Pathways to Health: The Role of Social Factors (Menlo Park, CA: Kaiser Family Foundation, 1989).

42. M.D. Wong, M.F. Shapiro, W.J. Boscardin, S.L. Ettner, "Contribution of Major Diseases to Disparities in Mortality," N. Engl. J. Med. 374. (2002): 1585-92; N.E. Adler and K. Newman, Socioeconomic Disparities in Health: Pathways and Policies, Health Affairs 21 (2002): 60-76.

43. R.A. Epstein, "Let the Shoemaker Stick to His Last: A Defense of the 'Old'

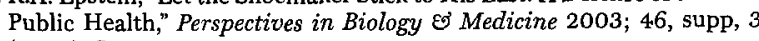
(2003): S138-59.

44. L.O. Gostin and M.G. Bloche, "The Politics of Public Health: A Reply to Richard Epstein," Perspectives in Biology छ Medicine 46, supp. 3 (2003): S160-75. R. Bayer, L.O. Gostin, and D. Magraw, "Trades, AIDS, and the Public's Health: The Limits of Economic Analysis," Georgetown Law Journal 83 (1995): 79-107.

45. National Association of Attorneys General, Master Settlement Agreement, available at <http://www.naag.org/upload/1032468605_cigmsa.pdfs

46. P.C. Weiler, H. Hiatt, J.P. Newhouse, et al., A Measure of Malpractice: Medical Injury, Malpractice Litigation, and Patient Compensation (Cambridge: Harvard University Press, 2000); L.T. Kohn, J.M. Corrigan, and M.S. Donaldson, eds., To Err is Human: Building a Safer Health System (Institute of Medicine 2000), available at $<$ http://www.nap.edu/books/0309068371/ html/>.

47. L.O. Gostin, The AIDS Pandemic: Complacency, Injustice, and Unfulfilled Expectations (University of North Carolina Press: 2004). 